\title{
A customized high-resolution array-comparative genomic hybridization to explore copy number variations in Parkinson's disease
}

\author{
Valentina La Cognata $^{1,2}$ - Giovanna Morello ${ }^{1}$ - Giulia Gentile ${ }^{1}$ - Velia D'Agata ${ }^{2}$. \\ Chiara Criscuolo $^{3}$ • Francesca Cavalcanti $^{4}$ - Sebastiano Cavallaro ${ }^{1,4}$
}

Received: 21 June 2016 / Accepted: 7 September 2016 / Published online: 17 September 2016

(C) The Author(s) 2016. This article is published with open access at Springerlink.com

\begin{abstract}
Parkinson's disease (PD), the second most common progressive neurodegenerative disorder, was long believed to be a non-genetic sporadic syndrome. Today, only a small percentage of PD cases with genetic inheritance patterns are known, often complicated by reduced penetrance and variable expressivity. The few well-characterized Mendelian genes, together with a number of risk factors, contribute to the major sporadic forms of the disease, thus delineating an intricate genetic profile at the basis of this debilitating and incurable condition. Along with single nucleotide changes, gene-dosage abnormalities and copy number variations (CNVs) have emerged as significant disease-causing mutations in PD. However, due to their size variability and to the quantitative nature of the assay, CNV genotyping is particularly challenging. For this reason, innovative high-throughput platforms and bioinformatics algorithms are increasingly replacing classical $\mathrm{CNV}$ detection methods. Here, we report the design strategy, development, validation and implementation of NeuroArray, a
\end{abstract}

Electronic supplementary material The online version of this article (doi:10.1007/s10048-016-0494-0) contains supplementary material, which is available to authorized users.

Sebastiano Cavallaro

sebastiano.cavallaro@cnr.it

1 Institute of Neurological Sciences, National Research Council, Catania, Italy

2 Department of Biomedical and Biotechnological Sciences, Section of Human Anatomy and Histology, University of Catania, Catania, Italy

3 Department of Neurosciences, Reproductive and Odontostomatological Sciences, Federico II University, Naples, Italy

4 Institute of Neurological Sciences, National Research Council, Mangone (CS), Italy customized exon-centric high-resolution array-based comparative genomic hybridization (aCGH) tailored to detect single/ multi-exon deletions and duplications in a large panel of PDrelated genes. This targeted design allows for a focused evaluation of structural imbalances in clinically relevant PD genes, combining exon-level resolution with genome-wide coverage. The NeuroArray platform may offer new insights in elucidating inherited potential or de novo structural alterations in PD patients and investigating new candidate genes.

Keywords aCGH $\cdot$ CNVs $\cdot$ Parkinson's disease $\cdot$ Neurological disorders · Genes

$\begin{array}{ll}\text { Abbreviations } \\ \text { aCGH } & \text { Comparative genomic hybridization array } \\ \text { AD } & \text { Alzheimer's disease } \\ \text { ALS } & \text { Amyotrophic lateral sclerosis } \\ \text { BMD } & \text { Becker muscular dystrophy } \\ \text { CNV } & \text { Copy number variation } \\ \text { DMD } & \text { Duchenne muscular dystrophy } \\ \text { HSP } & \text { Hereditary spastic paraplegia } \\ \text { LGMD } & \text { Limb-girdle muscular dystrophy } \\ \text { MLPA } & \text { Multiplex ligation-dependent probe amplification } \\ \text { NF } & \text { Neurofibromatosis } \\ \text { NGS } & \text { Next generation sequencing } \\ \text { PD } & \text { Parkinson's disease } \\ \text { PN } & \text { Peripheral neuropathy } \\ \text { qPCR } & \text { Quantitative polymerase chain reaction } \\ \text { RTT } & \text { Rett syndrome } \\ \text { SCA } & \text { Spinocerebellar ataxia } \\ \text { TSC } & \text { Tuberous sclerosis }\end{array}$




\section{Introduction}

Parkinson's disease (PD) is a progressive debilitating movement disorder that affects approximately $1 \%$ of the population older than 65 years of age worldwide [1]. Clinically, most patients present resting tremor, bradykinesia, stiffness of movement and postural instability. These major symptoms derive from the profound and selective loss of dopaminergic neurons in the substantia nigra pars compacta $(\mathrm{SNc})$, coupled with the accumulation of eosinophilic intracytoplasmic aggregates termed Lewy bodies (LBs) [1]. Like other complex diseases, PD is believed to be a multifactorial syndrome, resulting from an elaborate interplay of numerous elements (genes, susceptibility alleles, environmental exposures and geneenvironment interactions), and its molecular aetiology remains incompletely understood [2].

In recent years, the intensive efforts of the scientific community and the significant and rapid advancement of biotechnologies have fuelled several steps towards the elucidation of the genetic components of PD. Genomewide linkage scans and exome sequencing of wellcharacterized PD families have been successful in discovering disease-causing mutations in dominant $(S N C A$, $L R R K 2, V P S 35$ and the recent TMEM230), recessive (PARK2, PINK1, DJ1, DNAJC6) [2-4] and X-linked $(R A B 39 B)$ PD genes [5, 6]. Other genes, such as CHCHD2 and EIF4G1, are associated with familial PD inheritance but still require independent confirmations [7, 8]. Moreover, a set of genes related to atypical parkinsonian forms is known and includes ATP13A2, whose mutations cause the Kufor-Rakeb syndrome (PARK9) [9]. Despite the existence of these rare Mendelian monogenic forms, it is now clear that PD is a genetically heterogeneous and most likely complex disorder. This complexity is underlined by the notion that we are currently aware of dozens of loci, genes and risk factors that seem to contribute to PD $[2,10]$. These genes are involved in numerous cellular pathways, such as the ubiquitinproteasome system, synaptic transmission, autophagy, lysosomal autophagy, endosomal trafficking, mitochondrial metabolism, apoptosis and inflammatory mechanisms, all of which are generally implicated in neuronal cell death [11].

While the major pathogenic mutations are single nucleotide polymorphisms (SNPs) in the coding regions of PD-linked genes, the contribution of other types of DNA molecular defects (e.g. structural chromosome abnormalities such as $\mathrm{CNVs}$ ) to the genomic architecture is less emphasized but equally significant $[12,13]$. CNVs are unbalanced rearrangements larger than $50 \mathrm{bp}$ and arise from genomic instability [12]. They are recognized as critical elements for the development and maintenance of the nervous system and appear to contribute to hereditable or sporadic neurological diseases, including neuropathies, epilepsy, autistic syndromes, psychiatric illnesses and neurodegenerative diseases, such as PD [14-16]. In this regard, several CNVs have been reported in PD patients, including specific pathogenic anomalies mapped in PD loci or involving candidate PD-related genes [17]. To mention the most recurrent, SNCA copy-number gains have been proven to play a major role in the disease severity of PARK1, while PARK2 homozygous or compound heterozygous exon copy number changes are very common among the early-onset cases, rendering the gene-dosage assay essential in mutational screening.

Currently, the detection of CNVs and gene dosage imbalances mainly relies on traditional methodological approaches (karyotyping and PCR-based approaches such as quantitative PCR and multiple ligation probe analysis). However, these methodologies bear objective limits: they are time-consuming and labour-intensive, require multiple phase steps and severe equipment costs and, above all, do not provide a complete genomic overview of structural imbalances at sufficiently high resolution. The development of the array-based comparative genomic hybridization (aCGH) technology has dramatically improved and catalysed the detection and characterization of multiple CNVs, offering high reproducibility, high resolution and scalability for complete genome-wide mapping of imbalances [18]. The aCGH technique has been refined to the most advanced aCGH plus SNP edition, a widely used array able to simultaneously perform SNP genotyping and CNV detection. This methodology shows higher sensitivity for the detection of low-level mosaic aneuploidies and chimerism and offers the ability to detect loss of heterozygosity, but it has a limited ability to detect single-exon CNVs due to the distribution of SNPs across the genome. For this reason, several customized aCGHs suitably designed to focus on specific clinically relevant chromosomal locations have been developed and are already applied to different human diseases, including neuromuscular diseases, cancer, autism, epilepsy, multiple sclerosis, mitochondrial and metabolic disorders [19-24].

In this study, we developed a customized exon-centric aCGH (hereafter called NeuroArray), tailored to detect single/multi-exon deletions and duplications in a large panel of PD-related genes. We will first report the design strategy and the applied analysis methods. Then, we will show two representative PD cases tested on NeuroArray. Our findings show the advantages of the NeuroArray platform in terms of results, time and costs, as well as for the discovery of new potential genetic biomarkers underlying the pathogenic mechanisms of PD and commonly shared genetic signatures with other neurological diseases. 


\section{Materials and methods}

\section{Gene selection and aCGH design strategy}

To build the customized NeuroArray aCGH platform, we aimed to obtain a high-density probe coverage in the coding region of clinically relevant genes associated with $\mathrm{PD}$. Gene selection relied on our expertise in the clinic, genetics and literature data and has been extended to the entire currently known sets of genes collected in PDGene (http://www. pdgene.org/) [25]. The list of selected genes embraces disease-causing genes, known and putative risk factors and other genetic regions affected by different types of mutations. To perform a differential diagnosis, we also included genes related to other neurological conditions (see Supplementary Information and Supplementary Tables).

The array design was carried out by using the web-based Agilent SureDesign Software (Agilent Technologies, Santa Clara, CA), a web application that allows one to define regions of interest and select the "best-performing" probes from the High-Density (HD) Agilent probe library. Candidate probes were scored and filtered using bioinformatics prediction criteria for probe sensitivity, specificity and responsiveness under appropriate conditions. We also selected a limited number of probes by genomic tiling to cover regions inadequately represented in the Agilent database. All probes had similar characteristics: isothermal probes, with melting temperature $(\mathrm{Tm})$ of $80^{\circ} \mathrm{C}$ and probe length of approximately 60 mers, in accordance with the manufacturer's specifications. Further details about the design method, the number of genes and exons, the median probe spacing and other characteristics of NeuroArray are summarized in Table 1, Supplementary Information and Supplementary Table 1.

\section{Clinical sample selection}

To validate the NeuroArray, we selected DNA samples from individuals suffering from PD or other neurological disorders and previously subjected to gene dosage through multiplex ligation-dependent probe amplification (MLPA), quantitative real-time polymerase chain reaction (qPCR) or other commercially available whole-genome aCGH. Moreover, DNA samples of patients with PD phenotypes but an incomplete molecular diagnosis were referred for NeuroArray molecular cytogenetic testing. Informed consent was obtained for the use of DNA samples and for the access to medical records for research purposes.

\section{Microarray experiment and data analysis}

Genomic DNA was extracted from peripheral blood lymphocytes using the EZ1 DNA Blood extraction kit (Qiagen, Hilden, Germany) by the BioRobot EZ1 following the manufacturer's
Table 1 Main characteristics of the customized PD panel

Customized PD panel design

Total genes

505

Total exonic targets $\quad 6826$

Target coverage $\quad 94 \%$

Total target/exon size $1935 \mathrm{Mbp}$

Total probes (1-2 probes per exon) $\quad 11,161$

Total unique probes from HD database $\quad 10,411$

Total unique probes by genomic tiling $\quad 750$

Median probe spacing $\quad 391 \mathrm{bp}$

Mean target size $\quad 323$ bp

Uncovered targets

431

The table lists the total number of selected genes and exon targets, the mean exon size, the number of probes, the median probe spacing and the total coverage of the customized design for CNV detection in PD. The array design was performed through the Agilent SureDesign software (https://earray.chem.agilent.com/suredesign/). The majority of probes have been scored and filtered from the High-Density (HD) Agilent probe library. A limited number of probes have been designed with the Genomic Tiling option to cover regions inadequately represented in the Agilent database. All probes have been chosen with similar characteristics: isothermal probes, with melting temperature $(\mathrm{Tm})$ of $80^{\circ} \mathrm{C}$ and probe length of 60-mers

recommendations (Qiagen, Hilden, Germany). Highly concentrated DNA was checked for quality using the NanoDrop spectrophotometer (Thermo Scientific, Wilmington, DE). Array experiments were performed as recommended by the manufacturer (Agilent Technologies, Santa Clara, CA), and data were extracted using Feature Extraction software (Agilent Technologies, Santa Clara, CA). After the quality control check, data visualization and analysis were performed with CytoGenomics software v. 3.0.6.6. (Agilent Technologies, Santa Clara, CA) using both ADM-2 and ADM-1 algorithms. Moreover, we took into account a single-probe analysis to include putative exonic variants. Significant single exonic probe signals were clustered for pathologies according to their location on causative or susceptibility genes through a homemade script on R-platform [26]. Full details on microarray experiments and data analysis are available in the Supplementary Information.

\section{Validation}

Ad hoc qPCR assays were performed to validate genomic imbalances detected by the NeuroArray as previously described [27]. Primers flanking the putative exonic imbalances were designed using the Primer-BLAST tool (http://www. ncbi.nlm.nih.gov/tools/primer-blast/). Each qPCR assay was performed in triplicate using the LightCycler 1.5 (Roche Diagnostics, Germany). The relative quantification was measured using the $\Delta \Delta \mathrm{Ct}$ method, which requires a healthy control sample (diploid) as a calibrator in all amplifications 
[28]. As a calibrator control, we used the same DNA reference hybridized in the NeuroArray experiments. A control gene, checked as normal double copies on NeuroArray, was used as a reference for normalization. We considered a $\Delta \Delta \mathrm{Ct}$ value $\leq 0.6$ as a loss, included from 0.8 to 1.2 as normal diploid, and $\geq 1.4$ as a gain. PCR products were visualized by agarose gel electrophoresis.

\section{Results}

\section{aCGH design on a targeted PD gene panel}

To perform a comprehensive analysis of CNVs in PD-related genes, we developed a focused customized oligonucleotide aCGH design targeting 505 genes and 6826 exonic regions linked to PD. Overall, 11,161 probes with a median probe spacing of $391 \mathrm{bp}$ were enriched in the coding regions of these genes (Table 1). The majority of targeted genes map on chromosome 1 , while lower numbers are distributed among the other chromosomes (Fig. 1).

The tightly restricted criteria used for the array customization have allowed a higher exonic probe enrichment on selected gene panels, overcoming the resolution of commercially available genome-wide CGH array platforms. Overall, $94 \%$ of the total exon targets are covered by at least one probe in the NeuroArray design (Table 1), while other commercially available aCGH platforms provide a lower probe coverage of the same selected exonic regions. For example, the Agilent SurePrint G3 Human CGH Microarray $8 \times 60 \mathrm{~K}$ slide format covers our selected regions by $8.2 \%$, while the highestresolution $1 \times 1 \mathrm{M}$ array provides $25 \%$ of our target coverage. A representative illustration is reported in Fig. 2 and focuses on PINK1 (RefSeq acc. no. NM_032409.2).

To perform an accurate differential analysis between PD patients and other neurological phenotypes, we also included genes related to other neurological disorders (Supplementary Information and Supplementary Tables). Specifically, 160 of the 505 PD-related genes were linked to other neurological conditions (Fig. 1).

\section{CNVs of PD-related genes detected through the NeuroArray platform}

NeuroArray was able to confirm copy number changes previously characterized by other methodological strategies and revealed new interesting genomic imbalances. In the following sections, we will show two representative examples of NeuroArray tests obtained by using genomic DNA samples of PD patients. Further CNVs were observed in other neurological disease-related panels and were validated by qPCR (data not shown).

\section{Application of an integrated ADM-1 and ADM-2 algorithm-based data analysis to improve CNV calling}

The DNA sample of patient no. 1 was referred to our laboratory for molecular testing of PARK2, PINK1 and DJ1, to confirm the clinical diagnosis of familial recessive early-onset PD. Mutation analysis showed a heterozygous C1305T single
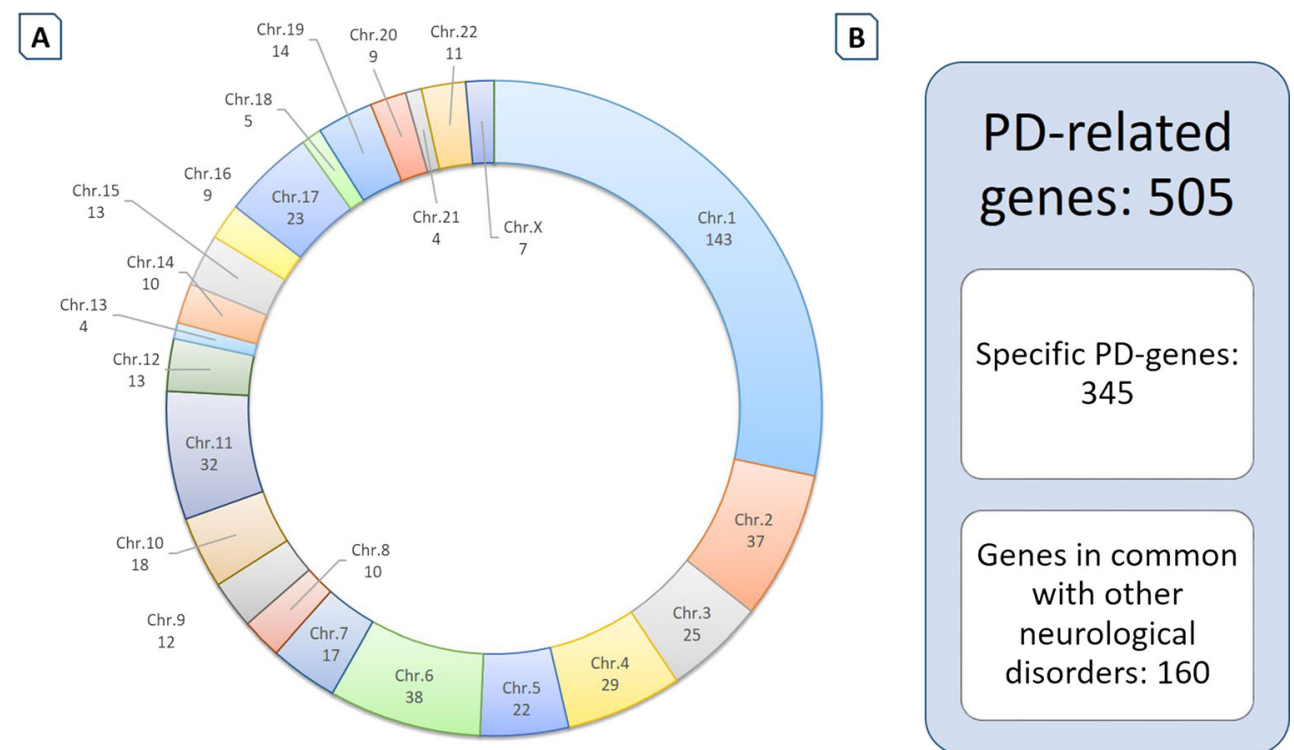

Fig. 1 Distribution of selected PD genes on the human genome and overlap with other neurological diseases. a Graphical representation showing the number of clinically relevant genes for chromosomes included in the customized PD panel. The total number of selected genes is 505 , mostly enclosed in chromosome 1 . Chromosome Y does not include PD-related genes. b The PD panel globally targets 505 PDrelated genes. Of these, 345 are specific for $\mathrm{PD}$, while 160 are in common with other neurological diseases. These latter ones can be useful to study the potential overlapping genetic signatures among different neurological conditions and to better define the genotype/phenotype correlations 


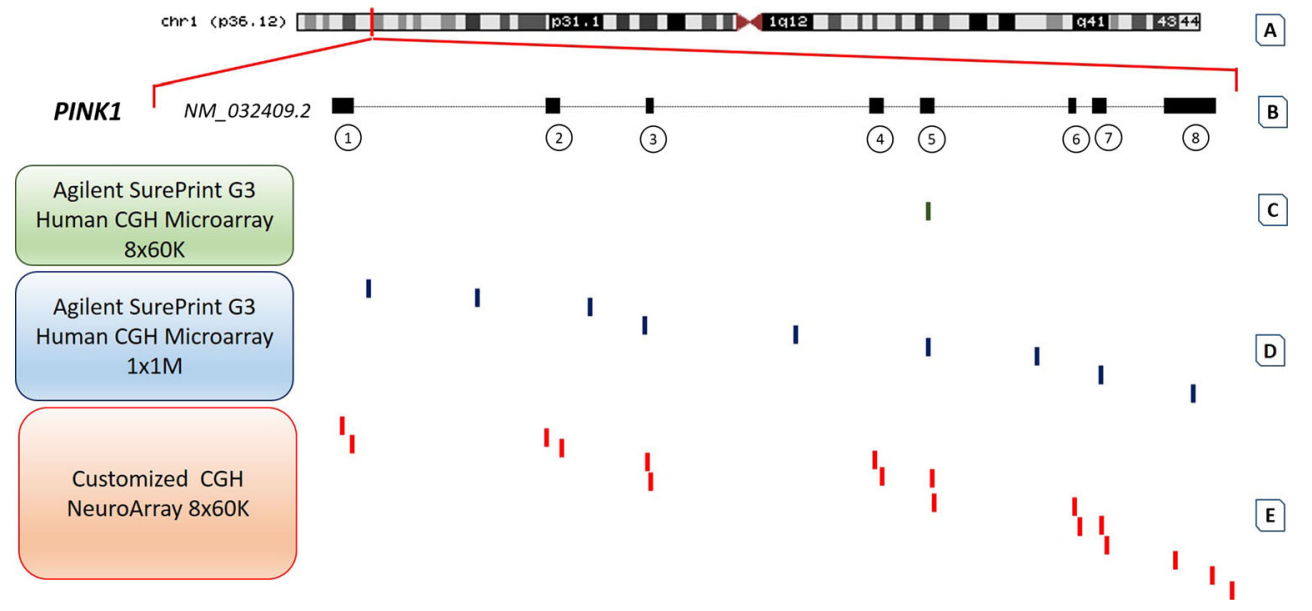

Fig. 2 Oligonucleotide probe distribution on PINK1 in different commercially available whole-genome aCGH platforms and NeuroArray. a The human PINK1 gene is located on chromosome 1 (cytoband p36.12), spanning approximately $18 \mathrm{~kb}$ of genomic DNA. b This gene produces an mRNA transcript encompassing eight exonic regions (NCBI accession number NM_032409.2). Exons are represented in the figure by black boxes and are numbered consecutively. The gray line represents intronic regions. c Distribution of oligonucleotide probes (green bars) in the commercially available whole-genome Agilent SurePrint G3 Human CGH Microarray $8 \times 60 \mathrm{~K}$. As evidenced in the figure, this platform has just one probe overlapping PINK1 exon 5, proving low-resolution coverage. d

nucleotide substitution in the coding region of PARK2. NeuroArray (with the ADM-1 algorithm) revealed 10 different CNVs, overall composed of 6 gains and 4 losses (Table 2). Four of them included genes previously linked to PD [29-32], while the others overlapped with genes related to other neurological conditions [33-42] (Table 2).

The most interesting findings regarded two principal dosage anomalies: (i) the gain of a 1442-kb region on chromosome 1, which encompasses PARK7, and (ii) the loss of the $N S F$ ( $N$-ethylmaleimide-sensitive factor) gene on chromosome 17 (Fig. 3a, b). Mutations in PARK7 comprehensively account for $\sim 1 \%$ of the early-onset familial cases [1], and its copy number changes have been previously observed in PD patients [43, 44]. NSF is involved in vesicular trafficking, membrane fusion and synaptic neurotransmission, and its genetic alterations (both SNPs and deletion) have been previously reported in PD patients $[31,45]$. Validations of these genomic rearrangements were performed with qPCR assays, suitably designed to target $P A R K 7$ exon 1 and $N S F$ exon 11 . Both assays confirmed the CNVs with $100 \%$ concordance and confirmed the heterozygous gain/loss (Fig. 3c). Primer sequences and PCR conditions are available upon request.

It should be highlighted that the default analysis with the ADM-2 algorithm revealed the loss of only the NSF gene. If this method were the only one applied, other relevant real CNVs (like the $P A R K 7$ gain, later confirmed by qPCR) would have been lost. On the other hand, the analysis with ADM-2 allowed for the filtering of possible false-positive CNVs
Distribution of oligonucleotide probes (blue bars) in the whole-genome Agilent SurePrint G3 Human CGH Microarray $1 \times 1 \mathrm{M}$ slide format. The highest-resolution $1 \times 1 \mathrm{M}$ array $\mathrm{CGH}$ reveals the PINK1 genetic region with a greater number of oligonucleotide probes; however, it is five times more expensive per sample than the Agilent $8 \times 60 \mathrm{~K}$ slide format and leaves uncovered some exonic traits (for example, exon 1 or 2 ). e Distribution of oligonucleotide probes (red bars) in the entire exonic regions of the PINK1 gene in the customized NeuroArray design. The NeuroArray design allows high-density probe enrichment in the entire exonic regions of $P I N K 1$, enabling a focused evaluation of structural imbalances at a single-exon resolution with costs comparable to an $8 \times 60 \mathrm{~K}$ slide format. (Colour figure online)

within the ADM-1 analysis. It appears important, therefore, to integrate data from both $\mathrm{CNV}$ calling algorithms in order to provide a more accurate data analysis and, consequently, ensure a more effective quality assessment and experimental validation.

\section{Detection of single-exon copy number changes by NeuroArray}

Although some authors have outlined the evidence that a significant proportion of single probe intervals represents real events [46], in aCGH studies, it is often recommended to report only intervals detected by three or more consecutive probes. Due to this approach, deletions or duplications below certain size cut-offs are usually ignored in the aCGH reports and not reported. However, these genomic alterations (detected by less than three probes) have been demonstrated to be definitively crucial for particular clinical diagnoses [47]. Along this line, we applied a single probe analysis to reveal short genomic imbalances in the exonic regions of strongly linked causative genes. The utility of this approach on NeuroArray data analysis is shown in the following case.

Patient no. 2 was a sporadic PD patient, carrying a heterozygous deletion of two adjacent exons ( 4 and 5) of the PARK2 gene. This deletion was previously revealed by an MLPA assay (SALSA MLPA Kit P051/P052 Parkinson; MRCHolland). The NeuroArray test was able to detect and confirm the deletion of exon 5 through two consecutive probes (Fig. 4) 


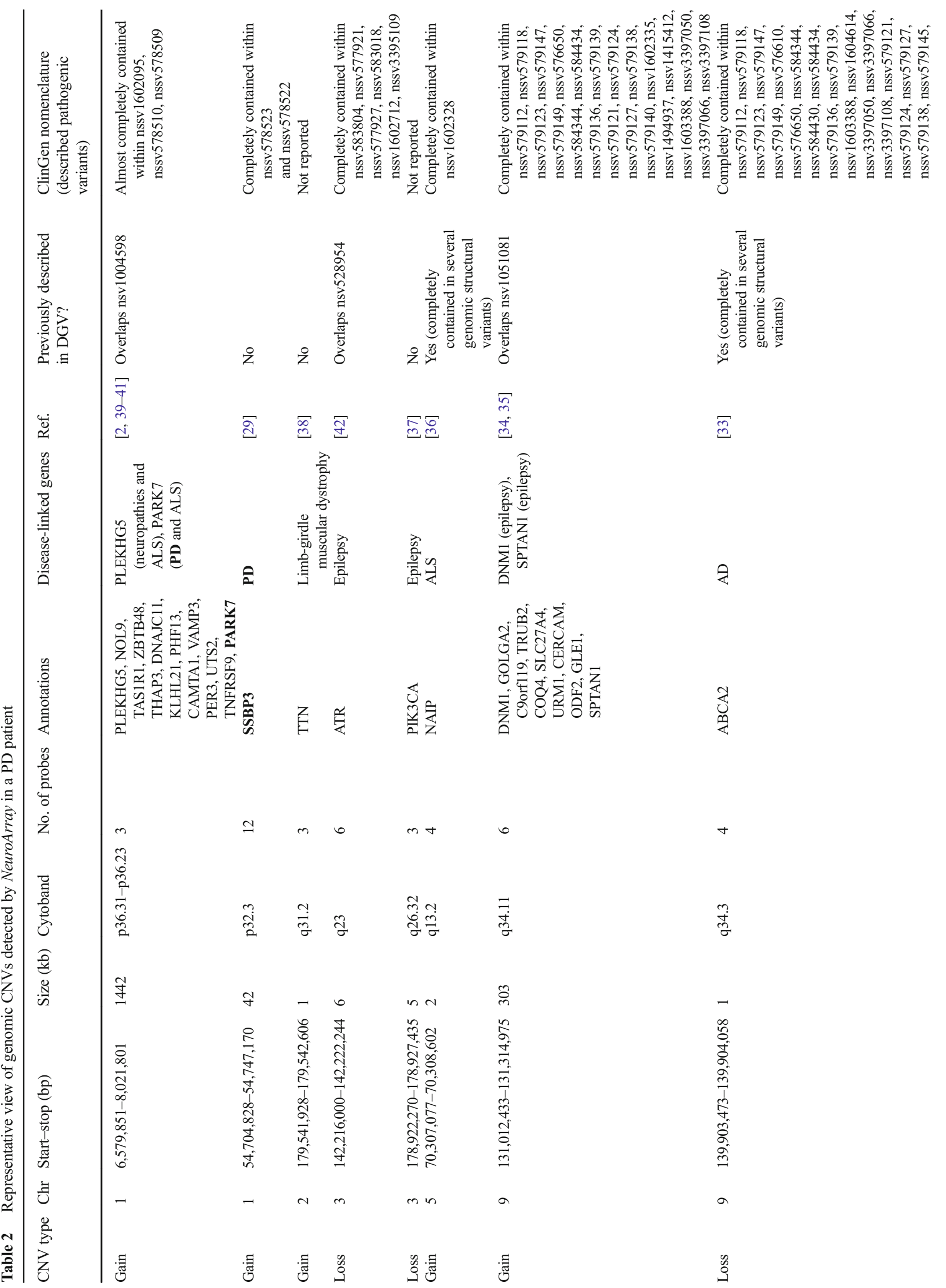


but was not able to detect the exon 4 deletion because during the phase of array design, this exon skipped the optimum parameters for probe coverage. The total concordance with the MLPA test was $91 \%$. Despite this limit, the one-probe analysis was essential to detect the exon 5 PARK2 deletion, which otherwise would not have been properly outlined using the analysis of three consecutive probes. However, this approach may result in a great number of false positives. Therefore, it is advisable to use it as a validation strategy for previously known exonic imbalances, i.e. next generation sequencing (NGS)-targeted panels, or to investigate copy number changes in a small set of strongly causative genes.

\section{Discussion}

In recent years, several studies have highlighted the key role of CNVs in the development of hereditable or sporadic neurological diseases, including PD [14-16]. Many gene-dosage anomalies have been previously mapped in PD patients, including familiar genes (SNCA, PARK2, PINK1, PARK7, ATP13A2) [48, 49], as well as several rare CNVs in candidate regions [45]. The aCGH biotechnology currently represents a useful tool for the detection of unbalanced chromosomal changes across the human genome, and its applications to screen common benign and rare pathogenetic CNVs are extensively growing [19-23]. The classical methodologic approaches are a gold-standard test when applied to monogenic disorders, but when applied to multigenic complex pathologies (such as PD), they require higher equipment costs, time, steps and personnel [50]. Conversely, targeted aCGH is rapid, relatively inexpensive, highly sensitive and an accurate method to simultaneously detect single- and multi-exon CNVs in numerous genes on a unique common platform. For this reason, several whole-genome and exon-targeted aCGH platforms have already been implemented in human diseases [19-24], and their utility has been demonstrated in patients with various clinical complex phenotypes [51-53].

In this study, we have designed and validated a targeted exon-centric aCGH platform (NeuroArray) as a molecular testing tool to simultaneously screen $\mathrm{CNV}$ imbalances in a large set of clinically relevant genes for PD and other complex neurological diseases. This customized design offers some considerable advantages: it allows an exon-focused evaluation of structural imbalances in clinically relevant regions at a higher resolution than whole-genome commercially available platforms and lowers the costs of an "exon by exon" analysis through PCR-based approaches, simultaneously providing an extensive window of further potentially involved genetic alterations.

In addition to the customized design, we also applied several approaches for data analysis. The first interesting result was the need to integrate data from both the ADM-1 and 
A

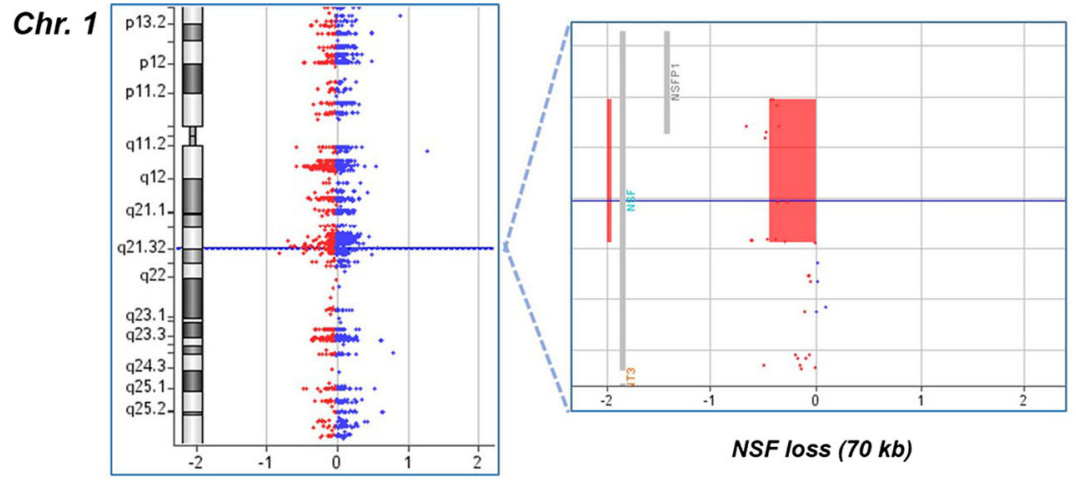

\section{B}
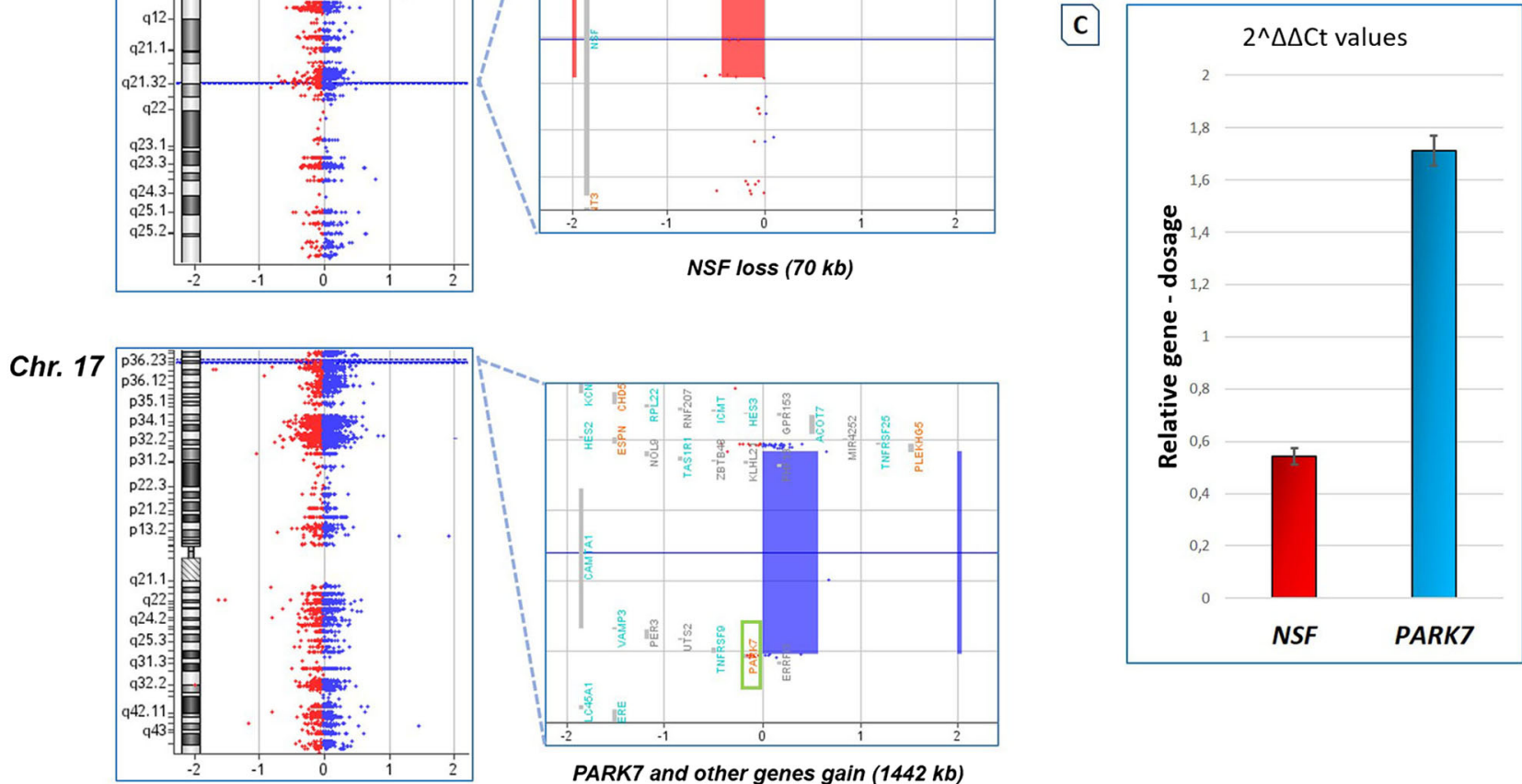

Fig. 3 A representative example of CNV detection involving PD-related genes in a patient with early-onset PD. The NeuroArray platform detected several CNVs in a female patient with early-onset PD and a mild phenotype (the reader is also referred to Table 2). a Visualization of the NSF deletion detected by NeuroArray as shown by CytoGenomics software. The left panel shows the entire chromosome 1, while the right panel is a zoom-in of the deleted region (indicated by the red area). Red and blue dots represent the $\log 2$ ratios for the relative hybridization intensities of each spotted probe. b Visualization of the PARK7 amplification detected by NeuroArray as shown by CytoGenomics software. The left panel shows the entire chromosome 17 , while the right panel is a zoom-in of the amplified region (indicated by the blue area). For red and blue dots, see a. Dots with an average $\log 2$ ratio of approximately +0.58 indicate a heterozygous amplification. c Validation of both CNVs of NSF and $P A R K 7$ by qPCR. Relative gene dosage levels of $N S F$ and $P A R K 7$ genes are based on delta $\mathrm{Ct}$ calculation. $\mathrm{Ct}$ values of both genes were normalized to the $\mathrm{Ct}$ value of a normal diploid gene. The relative level of each gene of

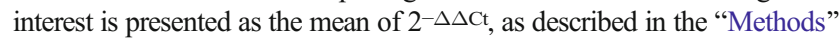
section. Error bars indicate standard deviations from the mean. (Colour figure online)

\section{A} Chr. 6 (cytoband 6q26), 100 bp heterozygous deletion

B

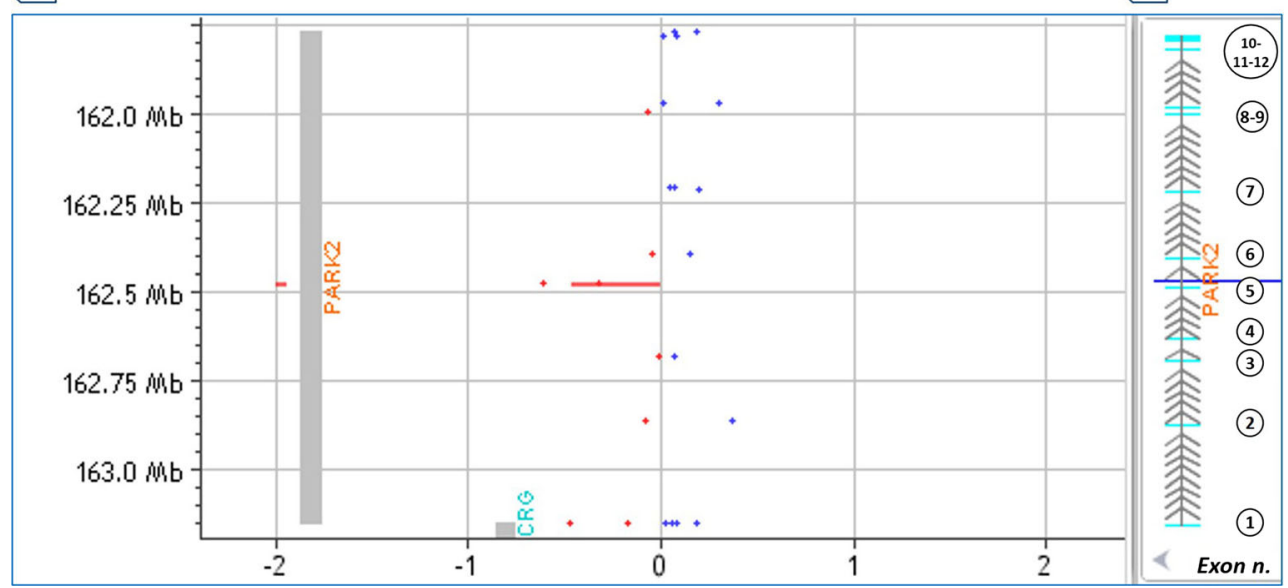

Fig. 4 Detection of intragenic PARK2 deletion (exon 5) in a patient with autosomal juvenile Parkinson's disease. Heterozygous deletion of exon 5 of the PARK2 gene detected by NeuroArray in a patient with juvenile Parkinson's disease (PD) and previously revealed by an MLPA assay. a NeuroArray aCGH data visualization and analysis as shown by CytoGenomics software. The red area represents the deleted region. The top of the panel shows the size of the deletion and the chromosomal locus.
Red and blue dots represent the $\log 2$ ratios for the relative hybridization intensities of each spotted probe. The dots with an average $\log 2$ ratio around -1 indicate a heterozygous deletion. b The panel displays the PARK2 gene as annotated in the UCSC Genome Browser Feb. 2009 GRCh37/hg19 (https://genome-euro.ucsc.edu). Blue boxes represent exons and are numbered consecutively, whereas grey arrows are the intronic regions. (Colour figure online) 
ADM-2 algorithms for $\mathrm{CNV}$ calling aberrations in order to reduce the number of false positives and to bring out relevant CNVs that otherwise would have been lost. We have also employed a one-probe analysis to reveal small imbalances at the single-exon level. Although this approach has the potential to detect crucial genetic variations ignored by multi-probe analysis, it largely increases the quantity of false-positive probe signals. Therefore, the single-probe analysis would be a useful validation strategy for NGS experiments or to investigate exon copy number changes in a smaller set of causative genes (as we performed with the script in the R-platform).

The use of dedicated high-throughput genotyping platforms like our NeuroArray could offer new opportunities for the PD genomic research field, mainly for familiar PD cases with an incomplete molecular diagnosis or sporadic cases without any detected genetic anomalies. The large-scale screening of genes that are involved in nervous system dysfunctions could allow for differential diagnosis with other common neurological disorders, refine the genotypephenotype correlations and explore the potential genetic overlapping signatures among different neurological conditions [54]. Specifically, the PD panel shares a good number of genes with other neurological diseases (Fig. 1). Given the existence of PD patients with combined clinical and pathological features [55-57], this strategy could be useful to investigate common genetic anomalies underlying very complex phenotypes.

Similarly to other aCGH-based technology, NeuroArray has some limitations, such as the inability to detect mosaicism poorly represented, balanced structural chromosomal abnormalities, nucleotide repeat expansions (e.g. in $C 90$ orf 72 or ATXN2 genes) and mutations included in regions not covered by probes. To overcome some of these limits and reduce the number of false-positive signals, we are developing a second version of the NeuroArray design with the aim of improving probe coverage in non-targeted genomic regions, including (where necessary) the intronic flanking regions and the alternatively spliced cassette exons of relevant PD genes [58-60].

\section{Conclusions}

Our NeuroArray platform represents a powerful and reliable tool for the analysis of genomic imbalances associated with PD and other neurological diseases. Compared to PCR-based approaches applied to multigene analysis or to whole-genome commercially available CGH arrays, it provides a focused higher resolution at a lower cost, enabling a more detailed analysis of clinically relevant exonic regions and offering a better cost/benefit ratio. In future years, the use of this platform may offer new insights into the investigation of new genetic molecular anomalies contributing to $\mathrm{PD}$, as well as a more precise definition of genotype-phenotype relationships.
It may also offer novel clues in the elucidation of potential genetic overlapping among different neurological conditions.

Acknowledgments This work was supported by the Italian Ministry of Education, Universities and Research through grant CTN01_00177_ 817708 and the international Ph.D. program in Neuroscience of the University of Catania. The authors gratefully acknowledge Cristina Calì, Alfia Corsino, Maria Patrizia D'Angelo and Francesco Marino for their administrative and technical support.

\section{Compliance with ethical standards}

Conflict of interest The authors declare that they have no conflict of interest.

Ethical approval Experiments involving human participants have been approved by an ethical committee for medical research and have been performed in accordance with ethical standards.

Informed consent Informed consent was obtained from all individual participants included in the study.

Open Access This article is distributed under the terms of the Creative Commons Attribution 4.0 International License (http:// creativecommons.org/licenses/by/4.0/), which permits unrestricted use, distribution, and reproduction in any medium, provided you give appropriate credit to the original author(s) and the source, provide a link to the Creative Commons license, and indicate if changes were made.

\section{References}

1. Moore DJ, West AB, Dawson VL, Dawson TM (2005) Molecular pathophysiology of Parkinson's disease. Annu Rev Neurosci 28: 57-87. doi:10.1146/annurev.neuro.28.061604.135718

2. Klein C, Westenberger A (2012) Genetics of Parkinson's disease. Cold Spring Harbor Perspect Med 2(1):a008888. doi:10.1101/ cshperspect.a008888

3. Deng HX, Shi Y, Yang Y, Ahmeti KB, Miller N, Huang C, Cheng L, Zhai H, Deng S, Nuytemans K, Corbett NJ, Kim MJ, Deng H, Tang B, Yang Z, Xu Y, Chan P, Huang B, Gao XP, Song Z, Liu Z, Fecto F, Siddique N, Foroud T, Jankovic J, Ghetti B, Nicholson DA, Krainc D, Melen O, Vance JM, Pericak-Vance MA, Ma YC, Rajput AH, Siddique T (2016) Identification of TMEM230 mutations in familial Parkinson's disease. Nat Genet 48(7):733-739. doi:10.1038/ng.3589

4. Olgiati S, Quadri M, Fang M, Rood JP, Saute JA, Chien HF, Bouwkamp CG, Graafland J, Minneboo M, Breedveld GJ, Zhang $\mathrm{J}$, International Parkinsonism Genetics N, Verheijen FW, Boon AJ, Kievit AJ, Jardim LB, Mandemakers W, Barbosa ER, Rieder CR, Leenders KL, Wang J, Bonifati V (2016) DNAJC6 mutations associated with early-onset Parkinson's disease. Ann Neurol 79(2): 244-256. doi:10.1002/ana.24553

5. Wilson GR, Sim JC, McLean C, Giannandrea M, Galea CA, Riseley JR, Stephenson SE, Fitzpatrick E, Haas SA, Pope K, Hogan KJ, Gregg RG, Bromhead CJ, Wargowski DS, Lawrence CH, James PA, Churchyard A, Gao Y, Phelan DG, Gillies G, Salce N, Stanford L, Marsh AP, Mignogna ML, Hayflick SJ, Leventer RJ, Delatycki MB, Mellick GD, Kalscheuer VM, D'Adamo P, Bahlo M, Amor DJ, Lockhart PJ (2014) Mutations in RAB39B cause X- 
linked intellectual disability and early-onset Parkinson disease with alpha-synuclein pathology. Am J Hum Genet 95(6):729-735. doi:10.1016/j.ajhg.2014.10.015

6. Mata IF, Jang Y, Kim CH, Hanna DS, Dorschner MO, Samii A, Agarwal P, Roberts JW, Klepitskaya O, Shprecher DR, Chung KA, Factor SA, Espay AJ, Revilla FJ, Higgins DS, Litvan I, Leverenz $\mathrm{JB}$, Yearout D, Inca-Martinez M, Martinez E, Thompson TR, Cholerton BA, Hu SC, Edwards KL, Kim KS, Zabetian CP (2015) The RAB39B p.G192R mutation causes X-linked dominant Parkinson's disease. Mol Neurodegener 10:50. doi:10.1186/ s13024-015-0045-4

7. Funayama M, Ohe K, Amo T, Furuya N, Yamaguchi J, Saiki $\mathrm{S}$, Li Y, Ogaki K, Ando M, Yoshino $\mathrm{H}$, Tomiyama $\mathrm{H}$, Nishioka K, Hasegawa K, Saiki H, Satake W, Mogushi K, Sasaki R, Kokubo Y, Kuzuhara S, Toda T, Mizuno Y, Uchiyama Y, Ohno K, Hattori N (2015) CHCHD2 mutations in autosomal dominant late-onset Parkinson's disease: a genome-wide linkage and sequencing study. Lancet Neurol 14(3):274-282. doi:10.1016/S1474-4422(14)70266-2

8. Chartier-Harlin MC, Dachsel JC, Vilarino-Guell C, Lincoln SJ, Lepretre F, Hulihan MM, Kachergus J, Milnerwood AJ, Tapia L, Song MS, Le Rhun E, Mutez E, Larvor L, Duflot A, VanbesienMailliot C, Kreisler A, Ross OA, Nishioka K, Soto-Ortolaza AI, Cobb SA, Melrose HL, Behrouz B, Keeling BH, Bacon JA, Hentati E, Williams L, Yanagiya A, Sonenberg N, Lockhart PJ, Zubair AC, Uitti RJ, Aasly JO, Krygowska-Wajs A, Opala G, Wszolek ZK, Frigerio R, Maraganore DM, Gosal D, Lynch T, Hutchinson M, Bentivoglio AR, Valente EM, Nichols WC, Pankratz N, Foroud T, Gibson RA, Hentati F, Dickson DW, Destee A, Farrer MJ (2011) Translation initiator EIF4G1 mutations in familial Parkinson disease. Am J Hum Genet 89(3):398-406. doi:10.1016/ j.ajhg.2011.08.009

9. Vilarino-Guell C, Soto AI, Lincoln SJ, Ben Yahmed S, Kefi M, Heckman MG, Hulihan MM, Chai H, Diehl NN, Amouri R, Rajput A, Mash DC, Dickson DW, Middleton LT, Gibson RA, Hentati F, Farrer MJ (2009) ATP13A2 variability in Parkinson disease. Hum Mutat 30(3):406-410. doi:10.1002/humu.20877

10. Lesage S, Brice A (2012) Role of Mendelian genes in "sporadic" Parkinson's disease. Parkinsonism Relat Disord 18(Supplement 1): S66-S70. doi:10.1016/S1353-8020(11)70022-0

11. Lin MK, Farrer MJ (2014) Genetics and genomics of Parkinson's disease. Genome Med 6(6):48. doi:10.1186/gm566

12. Zarrei M, MacDonald JR, Merico D, Scherer SW (2015) A copy number variation map of the human genome. Nat Rev Genet 16(3): 172-183. doi:10.1038/nrg3871

13. Carvalho CM, Lupski JR (2016) Mechanisms underlying structural variant formation in genomic disorders. Nat Rev Genet. doi:10.1038/nrg.2015.25

14. Lee JA, Lupski JR (2006) Genomic rearrangements and gene copynumber alterations as a cause of nervous system disorders. Neuron 52(1):103-121. doi:10.1016/j.neuron.2006.09.027

15. Kalman B, Vitale E (2009) Structural chromosomal variations in neurological diseases. Neurologist 15(5):245-253. doi:10.1097/ NRL.0b013e3181963cef

16. Wang L, Nuytemans K, Bademci G, Jauregui C, Martin ER, Scott WK, Vance JM, Zuchner S (2013) High-resolution survey in familial Parkinson disease genes reveals multiple independent copy number variation events in PARK2. Hum Mutat 34(8):10711074. doi:10.1002/humu. 22344

17. Pankratz N, Dumitriu A, Hetrick KN, Sun M, Latourelle JC, Wilk JB, Halter C, Doheny KF, Gusella JF, Nichols WC, Myers RH, Foroud T, DeStefano AL, Psg P, GenePd Investigators C, Molecular Genetic L (2011) Copy number variation in familial Parkinson disease. PLoS One 6(8):e20988. doi:10.1371/journal. pone.0020988
18. Shaw-Smith C, Redon R, Rickman L, Rio M, Willatt L, Fiegler H, Firth H, Sanlaville D, Winter R, Colleaux L, Bobrow M, Carter NP (2004) Microarray based comparative genomic hybridisation (array-CGH) detects submicroscopic chromosomal deletions and duplications in patients with learning disability/mental retardation and dysmorphic features. J Med Genet 41(4):241-248

19. Ferlini A, Bovolenta M, Neri M, Gualandi F, Balboni A, Yuryev A, Salvi F, Gemmati D, Liboni A, Zamboni P (2010) Custom CGH array profiling of copy number variations (CNVs) on chromosome $6 \mathrm{p} 21.32$ (HLA locus) in patients with venous malformations associated with multiple sclerosis. BMC Med Genet 11:64. doi:10.1186/ 1471-2350-11-64

20. Piluso G, Dionisi M, Del Vecchio BF, Torella A, Aurino S, Savarese M, Giugliano T, Bertini E, Terracciano A, Vainzof M, Criscuolo C, Politano L, Casali C, Santorelli FM, Nigro V (2011) Motor chip: a comparative genomic hybridization microarray for copy-number mutations in 245 neuromuscular disorders. Clin Chem 57(11): 1584-1596. doi:10.1373/clinchem.2011.168898

21. Inazawa J, Inoue J, Imoto I (2004) Comparative genomic hybridization (CGH)-arrays pave the way for identification of novel cancer-related genes. Cancer Sci 95(7):559-563

22. Wisniowiecka-Kowalnik B, Kastory-Bronowska M, Bartnik M, Derwinska K, Dymczak-Domini W, Szumbarska D, Ziemka E, Szczaluba K, Sykulski M, Gambin T, Gambin A, Shaw CA, Mazurczak T, Obersztyn E, Bocian E, Stankiewicz P (2013) Application of custom-designed oligonucleotide array CGH in 145 patients with autistic spectrum disorders. Eur J Hum Genet: EJHG 21(6):620-625. doi:10.1038/ejhg.2012.219

23. Mefford HC, Muhle H, Ostertag P, von Spiczak S, Buysse K, Baker C, Franke A, Malafosse A, Genton P, Thomas P, Gurnett CA, Schreiber S, Bassuk AG, Guipponi M, Stephani U, Helbig I, Eichler EE (2010) Genome-wide copy number variation in epilepsy: novel susceptibility loci in idiopathic generalized and focal epilepsies. PLoS Genet 6(5):e1000962. doi:10.1371/journal. pgen.1000962

24. Wang J, Rakhade M (2012) Utility of array CGH in molecular diagnosis of mitochondrial disorders. Methods Mol Biol 837: 301-312. doi:10.1007/978-1-61779-504-6_20

25. Lill CM, Roehr JT, McQueen MB, Kavvoura FK, Bagade S, Schjeide BM, Schjeide LM, Meissner E, Zauft U, Allen NC, Liu T, Schilling M, Anderson KJ, Beecham G, Berg D, Biernacka JM, Brice A, DeStefano AL, Do CB, Eriksson N, Factor SA, Farrer MJ, Foroud T, Gasser T, Hamza T, Hardy JA, Heutink P, Hill-Burns EM, Klein C, Latourelle JC, Maraganore DM, Martin ER, Martinez M, Myers RH, Nalls MA, Pankratz N, Payami H, Satake W, Scott WK, Sharma M, Singleton AB, Stefansson K, Toda T, Tung JY, Vance J, Wood NW, Zabetian CP, Me Genetic Epidemiology of Parkinson's Disease C, International Parkinson's Disease Genomics C, Parkinson's Disease GC, Wellcome Trust Case Control C, Young P, Tanzi RE, Khoury MJ, Zipp F, Lehrach H, Ioannidis JP, Bertram L (2012) Comprehensive research synopsis and systematic meta-analyses in Parkinson's disease genetics: the PDGene database. PLoS Genet 8(3):e1002548. doi:10.1371/ journal.pgen.1002548

26. Team RC (2014) R: A language and environment for statistical computing. R Foundation for Statistical Computing, Vienna, Austria, 2012. ISBN 3-900051-07-0

27. D'haene B, Vandesompele J, Hellemans J (2010) Accurate and objective copy number profiling using real-time quantitative PCR. Methods 50(4):262-270. doi:10.1016/j.ymeth.2009.12.007

28. Patitucci A, Muglia M, Magariello A, Gabriele AL, Peluso G, Sprovieri T, Conforti FL, Mazzei R, Ungaro C, Condino F, Valentino P, Bono F, Rodolico C, Mazzeo A, Toscano A, Vita G, Quattrone A (2005) Comparison of different techniques for detecting 17p12 duplication in CMT1A. Neuromuscul Disord 15(7):488492. doi:10.1016/j.nmd.2005.04.006 
29. Haugarvoll K, Toft M, Skipper L, Heckman MG, Crook JE, Soto A, Ross OA, Hulihan MM, Kachergus JM, Sando SB, White LR, Lynch T, Gibson JM, Uitti RJ, Wszolek ZK, Aasly JO, Farrer MJ (2009) Fine-mapping and candidate gene investigation within the PARK10 locus. Eur J Hum Genet: EJHG 17(3):336-343. doi:10.1038/ejhg.2008.187

30. Mo X, Liu D, Li W, Hu Z, Hu Y, Li J, Guo J, Tang B, Zhang Z, Bai Y, Xia K (2010) Genetic screening for mutations in the Nrdp1 gene in Parkinson disease patients in a Chinese population. Parkinsonism Relat Disord 16(3):222-224. doi:10.1016/j.parkreldis.2009.09.001

31. Liu X, Cheng R, Verbitsky M, Kisselev S, Browne A, MejiaSanatana H, Louis ED, Cote LJ, Andrews H, Waters C, Ford B, Frucht S, Fahn S, Marder K, Clark LN, Lee JH (2011) Genomewide association study identifies candidate genes for Parkinson's disease in an Ashkenazi Jewish population. BMC Med Genet 12: 104. doi:10.1186/1471-2350-12-104

32. Bonifati V, Rizzu P, van Baren MJ, Schaap O, Breedveld GJ, Krieger E, Dekker MC, Squitieri F, Ibanez P, Joosse M, van Dongen JW, Vanacore N, van Swieten JC, Brice A, Meco G, van Duijn CM, Oostra BA, Heutink P (2003) Mutations in the DJ-1 gene associated with autosomal recessive early-onset parkinsonism. Science 299(5604):256-259. doi:10.1126/science.1077209

33. Mace S, Cousin E, Ricard S, Genin E, Spanakis E, LafargueSoubigou C, Genin B, Fournel R, Roche S, Haussy G, Massey F, Soubigou S, Brefort G, Benoit P, Brice A, Campion D, Hollis M, Pradier L, Benavides J, Deleuze JF (2005) ABCA2 is a strong genetic risk factor for early-onset Alzheimer's disease. Neurobiol Dis 18(1):119-125. doi:10.1016/j.nbd.2004.09.011

34. Euro E-RESC, Epilepsy Phenome/Genome P, Epi KC (2014) De novo mutations in synaptic transmission genes including DNM1 cause epileptic encephalopathies. Am J Hum Genet 95(4):360 370. doi:10.1016/j.ajhg.2014.08.013

35. Tohyama J, Nakashima M, Nabatame S, Gaik-Siew C, Miyata R, Rener-Primec Z, Kato M, Matsumoto N, Saitsu H (2015) SPTAN1 encephalopathy: distinct phenotypes and genotypes. J Hum Genet 60(4):167-173. doi:10.1038/jhg.2015.5

36. Jackson M, Morrison KE, Al-Chalabi A, Bakker M, Leigh PN (1996) Analysis of chromosome 5q13 genes in amyotrophic lateral sclerosis: homozygous NAIP deletion in a sporadic case. Ann Neurol 39(6):796-800. doi:10.1002/ana.410390616

37. Lee JH, Huynh M, Silhavy JL, Kim S, Dixon-Salazar T, Heiberg A, Scott E, Bafna V, Hill KJ, Collazo A, Funari V, Russ C, Gabriel SB, Mathern GW, Gleeson JG (2012) De novo somatic mutations in components of the PI3K-AKT3-mTOR pathway cause hemimegalencephaly. Nat Genet 44(8):941-945. doi:10.1038/ ng. 2329

38. Zheng W, Chen H, Deng X, Yuan L, Yang Y, Song Z, Yang Z, Wu Y, Deng H (2015) Identification of a novel mutation in the titin gene in a Chinese family with limb-girdle muscular dystrophy $2 \mathrm{~J}$. Mol Neurobiol. doi:10.1007/s12035-015-9439-0

39. Hanagasi HA, Giri A, Guven G, Bilgic B, Hauser AK, Emre M, Heutink P, Basak N, Gasser T, Simon-Sanchez J, Lohmann E (2016) A novel homozygous DJ1 mutation causes parkinsonism and ALS in a Turkish family. Parkinsonism Relat Disord. doi:10.1016/j.parkreldis.2016.03.001

40. Kim HJ, Hong YB, Park JM, Choi YR, Kim YJ, Yoon BR, Koo H, Yoo JH, Kim SB, Park M, Chung KW, Choi BO (2013) Mutations in the PLEKHG5 gene is relevant with autosomal recessive intermediate Charcot-Marie-Tooth disease. Orphanet J Rare Dis 8:104. doi:10.1186/1750-1172-8-104

41. Ozoguz A, Uyan O, Birdal G, Iskender C, Kartal E, Lahut S, Omur O, Agim ZS, Eken AG, Sen NE, Kavak P, Saygi C, Sapp PC, Keagle P, Parman Y, Tan E, Koc F, Deymeer F, Oflazer P, Hanagasi H, Gurvit H, Bilgic B, Durmus H, Ertas M, Kotan D, Akalin MA, Gulluoglu H, Zarifoglu M, Aysal F, Dosoglu N, Bilguvar K, Gunel M, Keskin O, Akgun T, Ozcelik H, Landers
JE, Brown RH, Basak AN (2015) The distinct genetic pattern of ALS in Turkey and novel mutations. Neurobiol Aging 36(4):1764 . doi:10.1016/j.neurobiolaging.2014.12.032e1769-1718

42. Lemke JR, Riesch E, Scheurenbrand T, Schubach M, Wilhelm C, Steiner I, Hansen J, Courage C, Gallati S, Burki S, Strozzi S, Simonetti BG, Grunt S, Steinlin M, Alber M, Wolff M, Klopstock T, Prott EC, Lorenz R, Spaich C, Rona S, Lakshminarasimhan M, Kroll J, Dorn T, Kramer G, Synofzik M, Becker F, Weber YG, Lerche H, Bohm D, Biskup S (2012) Targeted next generation sequencing as a diagnostic tool in epileptic disorders. Epilepsia 53(8):1387-1398. doi:10.1111/j.1528-1167.2012.03516.x

43. Guo JF, Zhang XW, Nie LL, Zhang HN, Liao B, Li J, Wang L, Yan XX, Tang BS (2010) Mutation analysis of Parkin, PINK1 and DJ-1 genes in Chinese patients with sporadic early onset parkinsonism. J Neurol 257(7):1170-1175. doi:10.1007/s00415-010-5485-8

44. Hedrich K, Djarmati A, Schafer N, Hering R, Wellenbrock C, Weiss PH, Hilker R, Vieregge P, Ozelius LJ, Heutink P, Bonifati V, Schwinger E, Lang AE, Noth J, Bressman SB, Pramstaller PP, Riess O, Klein C (2004) DJ-1 (PARK7) mutations are less frequent than Parkin (PARK2) mutations in early-onset Parkinson disease. Neurology 62(3):389-394

45. Liu X, Cheng R, Ye X, Verbitsky M, Kisselev S, Mejia-Santana H, Louis E, Cote L, Andrews H, Waters C, Ford B, Fahn S, Marder K, Lee J, Clark L (2013) Increased rate of sporadic and recurrent rare genic copy number variants in Parkinson's disease among Ashkenazi Jews. Mol Genet Genomic Med 1(3):142-154. doi:10.1002/mgg3.18

46. de Smith AJ, Tsalenko A, Sampas N, Scheffer A, Yamada NA, Tsang P, Ben-Dor A, Yakhini Z, Ellis RJ, Bruhn L, Laderman S, Froguel P, Blakemore AI (2007) Array CGH analysis of copy number variation identifies 1284 new genes variant in healthy white males: implications for association studies of complex diseases. Hum Mol Genet 16(23):2783-2794. doi:10.1093/hmg/ddm208

47. Mendelsohn BA, Pronold M, Long R, Smaoui N, Slavotinek AM (2014) Advanced bone age in a girl with Wiedemann-Steiner syndrome and an exonic deletion in KMT2A (MLL). Am J Med Genet A 164A(8):2079-2083. doi:10.1002/ajmg.a.36590

48. Darvish H, Movafagh A, Omrani MD, Firouzabadi SG, Azargashb E, Jamshidi J, Khaligh A, Haghnejad L, Naeini NS, Talebi A, Heidari-Rostami HR, Noorollahi-Moghaddam H, Karkheiran S, Shahidi GA, Paknejad SM, Ashrafian H, Abdi S, Kayyal M, Akbari M, Pedram N, Emamalizadeh B (2013) Detection of copy number changes in genes associated with Parkinson's disease in Iranian patients. Neurosci Lett 551:75-78. doi:10.1016/j. neulet.2013.07.013

49. Toft M, Ross OA (2010) Copy number variation in Parkinson's disease. Genome Med 2(9):62. doi:10.1186/gm183

50. Tayeh MK, Chin EL, Miller VR, Bean LJ, Coffee B, Hegde M (2009) Targeted comparative genomic hybridization array for the detection of single- and multiexon gene deletions and duplications. Genet Med: Off J Am Coll Med Genet 11(4):232-240. doi:10.1097/ GIM.0b013e318195e191

51. Boone PM, Bacino CA, Shaw CA, Eng PA, Hixson PM, Pursley AN, Kang SH, Yang Y, Wiszniewska J, Nowakowska BA, del Gaudio D, Xia Z, Simpson-Patel G, Immken LL, Gibson JB, Tsai AC, Bowers JA, Reimschisel TE, Schaaf CP, Potocki L, Scaglia F, Gambin T, Sykulski M, Bartnik M, Derwinska K, WisniowieckaKowalnik B, Lalani SR, Probst FJ, Bi W, Beaudet AL, Patel A, Lupski JR, Cheung SW, Stankiewicz P (2010) Detection of clinically relevant exonic copy-number changes by array CGH. Hum Mutat 31(12):1326-1342. doi:10.1002/humu.21360

52. Tucker T, Zahir FR, Griffith M, Delaney A, Chai D, Tsang E, Lemyre E, Dobrzeniecka S, Marra M, Eydoux P, Langlois S, Hamdan FF, Michaud JL, Friedman JM (2014) Single exonresolution targeted chromosomal microarray analysis of known 
and candidate intellectual disability genes. Eur J Hum Genet: EJHG 22(6):792-800. doi:10.1038/ejhg.2013.248

53. Aradhya S, Lewis R, Bonaga T, Nwokekeh N, Stafford A, Boggs B, Hruska K, Smaoui N, Compton JG, Richard G, Suchy S (2012) Exon-level array CGH in a large clinical cohort demonstrates increased sensitivity of diagnostic testing for Mendelian disorders. Genet Med: Off J Am Coll Med Genet 14(6):594-603. doi:10.1038/gim.2011.65

54. Desikan RS, Schork AJ, Wang Y, Witoelar A, Sharma M, McEvoy LK, Holland D, Brewer JB, Chen CH, Thompson WK, Harold D, Williams J, Owen MJ, O'Donovan MC, Pericak-Vance MA, Mayeux R, Haines JL, Farrer LA, Schellenberg GD, Heutink P, Singleton AB, Brice A, Wood NW, Hardy J, Martinez M, Choi SH, DeStefano A, Ikram MA, Bis JC, Smith A, Fitzpatrick AL, Launer L, van Duijn C, Seshadri S, Ulstein ID, Aarsland D, Fladby T, Djurovic S, Hyman BT, Snaedal J, Stefansson H, Stefansson K, Gasser T, Andreassen OA, Dale AM (2015) Genetic overlap between Alzheimer's disease and Parkinson's disease at the MAPT locus. Mol Psychiatry. doi:10.1038/mp.2015.6

55. Zaleski C, Bassett AS, Tam K, Shugar AL, Chow EW, McPherson E (2009) The co-occurrence of early onset Parkinson disease and 22q11.2 deletion syndrome. Am J Med Genet A 149A(3):525-528. doi:10.1002/ajmg.a.32650
56. Annesi G, Savettieri G, Pugliese P, D'Amelio M, Tarantino P, Ragonese P, La Bella V, Piccoli T, Civitelli D, Annesi F, Fierro B, Piccoli F, Arabia G, Caracciolo M, Ciro Candiano IC, Quattrone A (2005) DJ-1 mutations and parkinsonism-dementia-amyotrophic lateral sclerosis complex. Ann Neurol 58(5):803-807. doi:10.1002/ana.20666

57. Chung SJ, Jung Y, Hong M, Kim MJ, You S, Kim YJ, Kim J, Song K (2013) Alzheimer's disease and Parkinson's disease genomewide association study top hits and risk of Parkinson's disease in Korean population. Neurobiol Aging 34(11):2695 . doi:10.1016/j. neurobiolaging.2013.05.022e2691-2697

58. La Cognata V, D'Agata V, Cavalcanti F, Cavallaro S (2015) Splicing: is there an alternative contribution to Parkinson's disease? Neurogenetics. doi:10.1007/s10048-015-0449-x

59. La Cognata V, Iemmolo R, D’Agata V, Scuderi S, Drago F, Zappia M, Cavallaro S (2014) Increasing the coding potential of genomes through alternative splicing: the case of PARK2 gene. Curr Genom 15(3):203-216. doi:10.2174/1389202915666140426003342

60. Scuderi S, La Cognata V, Drago F, Cavallaro S, D’Agata V (2014) Alternative splicing generates different parkin protein isoforms: evidences in human, rat, and mouse brain. Biomed Res Int 2014: 690796. doi: $10.1155 / 2014 / 690796$ 